\title{
Metanalysis Economical-Financial Performance of the Production of Milk and Goats on Systems of Family Farming
}

\author{
Olivan Cunha de Almeida \\ Universidade Federal do Maranhão, UFMA, campus de Chapadinha, Maranhão-Brazil. \\ E-mail: olivan.almeida.tec@gmail.com
}

Ricardo Alves de Araújo (Corresponding author)

Professor, Universidade Estadual do Maranhão, Itapecuru mirim, Maranhão-Brazil.

E-mail: ricardo_zoo@hotmail.com

Luiza de Nazaré Carneiro da Silva

Universidade Federal do Tocantins, UFT, campus de Araguaína, Tocantins-Brazil.

E-mail: luiza.zootecnia@gmail.com

Edmilson Igor Bernardo Almeida

Universidade Federal do Maranhão, UFMA, campus de Chapadinha, Maranhão-Brazil.

E-mail: edmilson_i@hotmail.com

Khalil de Menezes Rodrigues

Universidade Federal do Maranhão, UFMA, campus de Chapadinha, Maranhão-Brazil.

E-mail: agrokhalil@yahoo.com.br

Clésio dos Santos Costa

Universidade Federal do Ceará, UFC, campus do Pici, Ceará-Brazil. 
E-mail: clesiosantzoo@gmail.com

Ivone Rodrigues da Silva

Universidade Federal do Piauí, UFPI, campus de Teresina, Piauí-Brazil.

E-mail: ivonerodrigues10@ hotmail.com

Felipe Araújo Oliveira da Silva

Universidade Federal do Maranhão, UFMA, campus de Chapadinha, Maranhão-Brazil.

E-mail: felipezoo25@outlook.com

Diego de Almeida Veras

Universidade Federal do Maranhão, UFMA, campus de Chapadinha, Maranhão-Brazil.

E-mail: verasdiego27@gmail.com

Maurivan Barbosa Pacheco

Universidade Federal do Maranhão, UFMA, campus de Chapadinha, Maranhão-Brazil.

E-mail: maurivanpacheco@gmail.com

Vanessa Brito Barroso

Universidade Federal do Maranhão, UFMA, campus de Chapadinha, Maranhão-Brazil. E-mail: vanessaflicka@hotmail.com

Received: July 5, 2020

doi:10.5296/jas.v8i4.17304
Accepted: Sep. 2, $2020 \quad$ Published: Sep. 3, 2020

URL: https://doi.org/10.5296/jas.v8i4.17304

\begin{abstract}
This study aimed to evaluate the economic and financial viability of the creation of dairy goats of Saanen breed and Anglo Nubian in system of family farming. The information of the technical parameters for financial analysis of this research were obtained in manuscripts the published in the last ten years in national journals. In face of these data was conducted a
\end{abstract}


meta-analysis of data which generated the zootechnical date used for the simulations in this work. The simulation for milk production and calves from 72 dairy goats provided revenue above the cost of production, resulting in positive economic indicators for both scenarios assessed. The revenue generated by the systems that utilize the Saanen goats are bigger, considering that the production is greater. The financial analysis of systems proved to be viable over 8 years. In relation to the payback, both presented low return on investment applied. Sensitivity analyzes showed that in both systems evaluated, only in the most unfavorable situations, such as a reduction of $30 \%$ in both production and market price, the indicators of economic performance are not attractive, given that the time of return on investment is too long, especially in the rearing of goats Anglo Nubian. From the practical point of view, it is recommended the creation of both breeds, because the cost of deployment of the system can be purchased via funding.

Keywords: Anglo Nubian, costs of production, profitability, Saanen

\section{Introduction}

The rearing of dairy goats has been growing in the Northeast region of Brazil. Social programs become important and encourage small producers to purchase animals and invest in livestock improvement. One of the main problems to sustain the goat's milk production chain is the cost of production that makes it impossible for small producers, who without capital, cannot cope with moments of crisis in the sector (Araújo et al., 2018). In this way, it is important that the producer adopt technologies to intensify production systems, being the containment a potential alternative, since despite increasing costs with food, guarantees the producer a fast return on invested capital (Pinto et al., 2014).

In this way, it is necessary that the diets meet the requirements of the animal (lower cost concurrently with a better performance), to obtain the best results and economic indicators that justify the maintenance of activity (Ziguer et al., 2011). It should be pointed out that the studies that perform economic analysis of dairy goats are scarce and, in most cases, present incomplete not composing the total cost of production.

In addition, estimates of production costs, the study of economic viability and investment is the first step for the beginning of economic evaluation and are fundamental for the proper characterization of a production system. In this way, allows the producer to the monitoring of values and of all transactions carried out on the property, important aspects to evaluate better the activity and that it is possible to reduce costs, increase productivity and establish goals to achieve high profitability with efficiency and sustainability, allowing the discovery of causes for the achievement of profit or loss (Stivari et al., 2014). Considering the possibility of expanding the dairy goat production chain, mainly from the economic point of view, attributing efficient allocation to the generated products. Thus, the hypothesis of this study is that there is the possibility of economically producing milk and goats in family farming. In this way, considering the possibility of expansion in the goat milk production in the Northeast region, this study aimed to evaluate the economic and financial viability of Saanen goats and Anglo Nubian fed on systems of family agriculture. 


\section{Material and Methods}

The information of the technical parameters for financial analysis of this research were obtained in the published in the last ten years in national journals. In face of these data was conducted a meta-analysis of data which generated the zootechnical data used for the simulations in this work. In this way, have been simulated two systems of animal production, one with the data of the Saanen and another with the data from the goats of the Anglo Nubian.

The collection of scientific articles for review of literature, scientific systematization / training base and meta-analytical study comprised of public domain works in descending chronological order starting from the initial moment of collection (January 2008) until December 2018. The same should contain performance data from dairy goats (Saanen and Anglo Nubian), jointly with the milk yield (kg/day), consumption of dry matter (pregnancy and lactation). After the recovery of all works were read in their entirety, in order to select for tabulation in Microsoft Excel ${ }^{\circledR}$ spreadsheet.

The economic and financial evaluation of the data was carried out in a descriptive way, using the Excel ${ }^{\circledR}$ spreadsheets, which enables the analysis of the cost of production and the economic viability indicators derived from the same. The investments relating to the implementation of the system of production were: fold with a total area of $144 \mathrm{~m}^{2}$, with $50 \%$ of this area, covered, and the other $50 \%$, constituting a solarium, as described in Table 1 . In addition, were part of the investment in the acquisition of equipment for production of arrays, such as forage.

Table 1. Cost of materials and labor for construction of a shed of masonry with 72 square meters and capacity for 72 goats

\begin{tabular}{lcccc}
\hline Items & Quantity & Unity & Unity price $(\mathrm{R} \$)$ & Total price $(\mathrm{R} \$)$ \\
\hline Wooden & 240 & Linear meter & 7.00 & $1,680.00$ \\
Roof & 72 & Square meter & 120.00 & $8,640.00$ \\
Trough & 18 & Linear meter & 17.00 & 306.00 \\
Fountain & 8 & Bucket & 6.00 & 48.00 \\
Workmanship & 6 & Diary & 100.00 & 600.00 \\
Balance & 1 & Piece & 200.00 & 200.00 \\
Wire & 1.000 & Linear meter & 0.50 & 500.00 \\
\hline Total price & & & & $11,974.00$ \\
\hline
\end{tabular}

The economic analysis was based on the calculation of cost of production, which is represented by the sum of all resources (inputs) and operations (services) used in the production process. The variable cost was composed by food, health, labor, equipment maintenance, depreciation, opportunity costs, and other costs (power of the wielder, specifications on zootechnics and electrical energy) (Guiducci et al., 2012). These expenses were raised on the basis of quotations of prices of products in the municipality of Chapadinha, Maranhão, Brazil, in September 2019. Feed costs were composed unbeatable prices and quantities supplied the ingredients of diets, based on dry matter. As the cost of labor, we considered the maintenance of an employee on temporary scheme to deal with a lot of 72 confined animals. The remuneration was based on the minimum wage in January 2019 ( $\mathrm{R} \$$ 998.00). This employee was considered as an integral part of the family, because it was 
considered if the payment of the labor force for the analysis have more economic foundation.

The indicators of economic efficiency were: total revenue (RV), total cost (TC), family income (FI), point of leveling (PL), rate of return the entrepreneur (RRe) and total factor productivity (TFP), calculated as Guiducci et al. (2012). The financial indicators considered were: net present value (NPV), annualized net present value (VPLa), term of return on investment (Payback), internal rate of return (IRR), modified internal rate of return (IRRm) and profitability index (PI), calculated as Guiducci et al. (2012).

In milk production systems simulated, both males and females, after birth were forwarded to the sale before that it was intended to recreate. The animals remained for a period of 30 days, being fed twice a day with milk from the first ten days of lactation, with the use of the bottle. As the principal activities of the evaluated systems are the milk and the sale of goats, the animals remain on the canvas for a short period, not to reduce the production and marketing of milk. The purchase price of the goats was $\mathrm{R} \$ 500.00$ for the Saanen and $\mathrm{R} \$ 400.00$ for the Anglo Nubian, considered as an investment and not as cost of production and the selling price was $\mathrm{R} \$ 1.10$ for a liter of milk produced, $\mathrm{R} \$ 170.00$ for the goats kids females and $\mathrm{R} \$ 150.00$ the goats kids males, of both races. It is considered that the animals from the property received a diet formulated with corn and soybean meal (SM) and was used as roughage hay tifton 85, in accordance with the requirements of animals in this category (NRC, 2007).

The complete base data for meta-analysis covered experiments with dry matter intake: a) treatments Saanen goats in lactation; b) Anglo Nubian goats in lactation; c) Saanen goats in pregnancy; d) goats Anglo Nubian in pregnancy. In addition, the milk production of both races. For the statistical analyzes were performed several divisions in the general basis using the resources of the Excel spreadsheet before being transferred to perform the analyzes using the SISVAR program 5.6.

The models were selected by the "Backward Method", being that the fixed factors tested only remained in the chosen models when, in addition to significant influenced above three percentage points the same. The tested factors as covariates in the analysis of the response variables remained significant when only for the template. The differences between experiments were considered as being the result of the variability of random sampling. Therefore, the effect of continuous relevant factors on the response variables of animal performance were analyzed as covariates in a model in which the purpose of the experiment was included as a fixed factor. The equations (model) were obtained using the bases Saanen and Anglo Nubian originated from the division of general basis. Before the data from the meta-analysis, it was the following livestock performance data (Table 2).

Table 2. Dry matter intake (DMI) during pregnancy and lactation and milk production (MP) of Saanen goats and Anglo Nubian

\begin{tabular}{lccc}
\hline \multirow{2}{*}{ Breed } & \multicolumn{3}{c}{ Data from the meta-analysis } \\
\cline { 2 - 4 } & $\begin{array}{c}\text { DMI in pregnancy } \\
\text { (g/day) }\end{array}$ & $\begin{array}{c}\text { DMI in lactation } \\
\text { (g/day) }\end{array}$ & $\begin{array}{c}\text { Production of milk } \\
\text { (g/day) }\end{array}$ \\
\hline Saanen & $1,199.68$ & $2,166.59$ & 1,480 \\
Anglo Nubian & $1,183.63$ & $2,015.58$ & 1,420 \\
\hline
\end{tabular}


The results of the zootechnical parameters obtained through the meta-analysis have been extrapolated to a system of 72 breeding goats, two, three births every two years and pregnancy, being half of young male and the other female half. This extrapolation was performed to ensure that the economic/financial analysis could be performed on scientific basis and in economies of scale.

\section{Results and Discussion}

We can observe that in the scenarios assessed in this study, feeding, labor costs and the opportunities were the items that most contributed to the costs of production, regardless of race evaluated (Table 3). It was observed that the two systems evaluated, the costs with the feeding of the Saanen goats were superior to Anglo Nubian, where for the first, about R\$16,515.84 were spent with the power, around R $\$ 948.84$ more than the Anglo Nubian. The annual costs for the creation of the goats recorded in this study corroborate with several authors (Dal Monte et al., 2010; Barros et al., 2015; Carvalho et al., 2011; Pinto et al., 2014; Stivari et al., 2014), which observed that, among the items that make up the costs of production of ruminants, in a general way, the costs of supply is the item of greatest impact on the total cost of production.

Table 3. Costs for the production of 72 dairy goats during the first year

\begin{tabular}{lcccc}
\hline Items & $\begin{array}{c}\text { Saanen } \\
(\mathrm{R} \$)\end{array}$ & $\begin{array}{c}\text { Percentage } \\
(\%)\end{array}$ & $\begin{array}{c}\text { Anglo Nubian } \\
(\mathrm{R} \$)\end{array}$ & $\begin{array}{c}\text { Percentage } \\
(\%)\end{array}$ \\
\hline Feeding & $16,515.84$ & 48.28 & $15,567.50$ & 47.27 \\
Sanity & 468.00 & 1.37 & 468.00 & 1.42 \\
Workmanship & $11,448.00$ & 33.47 & $11,448.00$ & 34.76 \\
Other Costs & 106.00 & 0.31 & 106.00 & 0.32 \\
Maintenance & 582.15 & 1.70 & 582.15 & 1.77 \\
Depreciation & 451.58 & 1.32 & 451.58 & 1.37 \\
Opportunity Costs & $4,633.89$ & 13.55 & 4.307 .63 & 13.08 \\
\hline TOTAL & $34,205.46$ & 100 & $32,930.86$ & 100 \\
\hline
\end{tabular}

${ }^{1}$ Tax on Rural Land Ownership and Incra.

One of the major obstacles of the dairy goat farming is, without a shadow of a doubt, the high mortality with diseases that affect the flock (Vieira et al., 2018). However, one must emphasize that the two systems evaluated, the costs with animal remained below $1.5 \%$ of all capital needed to maintain the 72 dairy goats, showing that despite the great health difficulty found by goat farmers, expenditure on medicines and health treatments proved to be a small portion of annual costs. Similarly, the maintenance of the installations and improvements has been a factor that less charged the costs of both systems, ranging from 1.70 to $1.77 \%$. In relation to workmanship, it can be observed that, although the remuneration be equal for the two systems, the percentage for this factor was greater in the rearing of goats of the breed Anglo Nubian (34.76\%).

The third factor that contributed most to the costs of the systems were the opportunity costs where, in percentage terms, the system of animal husbandry of the Saanen presented higher opportunity cost (13.55\%), around $\mathrm{R} \$ 4,633.89$. Since the system of goat rearing Anglo Nubian (13.08\%), which corresponds to $\mathrm{R} \$ 4,307.63$. It should be emphasized that the opportunity cost should not be understood as an actual disbursement of the creator of dairy 
goats and yes as income implied. In this way, all the factors of production (land, workmanship and capital) are being paid and computed for a better economic analysis of each production system. When all these components are included, even if the profit is zero, there would be no reason for which the producer to abandon the activity, because it is getting through the use of their own factors of production (Stivari et al., 2014). Thus, it appears that in this research, the two systems evaluated, that profit is positive, making then, the production of Saanen goats and/or Anglo Nubian viable, since the producer is getting through all the factors of production.

As described earlier, the production system of goats Saanen had the greatest cost with feeding. In a more detailed manner, it can be observed that the average cost of the kilo of diet was $\mathrm{R} \$ 1.16$ (Table 4). The components of the ration, the tifton hay and corn were those who had greater participation in the price of diet, approximately 49.50 and $40.75 \%$, respectively. It can be observed that the quantity of feed needed is $14,305.13 \mathrm{~kg} / \mathrm{year}$. The average cost with feed per animal in the system of creation Saanen was on average $\mathrm{R} \$ 229.39$. In this way, the cost to feed a flock with 72 animals is $R \$ 16,515.84$, being most intended for the purchase of hay $(\mathrm{R} \$ 8,175.78)$ and maize $(\mathrm{R} \$ 6,730.47)$.

Table 4. Annual quantity of ration, cost per kilo, annual cost and cost per head for 72 dairy goats of Saanen breed

\begin{tabular}{lccccc}
\hline Ingredient & $\begin{array}{c}\mathrm{AQ}^{1} \\
(\mathrm{~kg})\end{array}$ & $\begin{array}{c}\mathrm{CK}^{2} \\
(\mathrm{R} \$)\end{array}$ & $\begin{array}{c}\mathrm{AC}^{3} \\
(\mathrm{R} \$)\end{array}$ & $\begin{array}{c}\mathrm{CH}^{4} \\
(\mathrm{R} \$)\end{array}$ & $\begin{array}{c}\text { Percentage } \\
(\%)\end{array}$ \\
\hline Tifton hay & $7,171.74$ & 1.14 & $8,175.78$ & 113.55 & 49.50 \\
Maize & $6,349.50$ & 1.06 & $6,730.47$ & 93.48 & 40.75 \\
Soybean meal & 745.74 & 2.12 & $1,580.96$ & 21.96 & 9.57 \\
Limestone & 38.16 & 0.75 & 28.62 & 0.40 & 0.17 \\
Total & $14,305.13$ & 1.16 & $16,515.84$ & 229.39 & 100 \\
\hline
\end{tabular}

${ }^{1} \mathrm{AQ}$ : annual quantity; ${ }^{2} \mathrm{CK}$ : cost per kilogram; ${ }^{3} \mathrm{AC}$ : Annual Cost; ${ }^{4} \mathrm{CH}$ : Cost per head

In the system of goat rearing Anglo Nubian the required amount of ration is around 13,466.28 $\mathrm{kg}$, which corresponds to exactly $\mathrm{R} \$ 15,567.50$. Of this total, approximately $47.27 \%$ is intended for the roughage in the diet, a higher percentage, which is equivalent to $6,455.77 \mathrm{~kg}$. Over the course of a year, the cost of soybean meal in the diet corresponds to $10.13 \%$ of the expenses with the ration consumed by goats Anglo Nubian, and $42.40 \%$ with maize.

Table 5. Annual quantity of ration, cost per kilo, annual cost and cost per head for 72 dairy goats of the Anglo Nubian in confinement

\begin{tabular}{lccccc}
\hline Ingredient & $\begin{array}{c}\mathrm{AQ}^{1} \\
(\mathrm{~kg})\end{array}$ & $\begin{array}{c}\mathrm{CK}^{2} \\
(\mathrm{R} \$)\end{array}$ & $\begin{array}{c}\mathrm{AC}^{3} \\
(\mathrm{R} \$)\end{array}$ & $\begin{array}{c}\mathrm{CH}^{4} \\
(\mathrm{R} \$)\end{array}$ & $\begin{array}{c}\text { Percentage } \\
(\%)\end{array}$ \\
\hline Tifton hay & $6,455.77$ & 1.14 & $7,359.58$ & 102.22 & 47.27 \\
Maize & $6,228.40$ & 1.06 & $6,602.11$ & 91.70 & 42.40 \\
Soybean meal & 743.97 & 2.12 & $1,577.21$ & 21.91 & 10.13 \\
Limestone & 38.13 & 0.75 & 28.60 & 0.40 & 0.18 \\
Total & $13,466.28$ & 1.16 & $15,567.50$ & 216.22 & 100 \\
\hline
\end{tabular}

${ }^{1} \mathrm{AQ}$ : annual quantity; ${ }^{2} \mathrm{CK}$ : cost per kilogram; ${ }^{3} \mathrm{AC}$ : Annual Cost; ${ }^{4} \mathrm{CH}$ : Cost per head

We can observe that the simulation for milk production and calves from 72 goats provided 
revenue above the cost of production, resulting in positive economic indicators for all the two scenarios assessed (Table 6). The revenue generated by the systems that utilize the Saanen goats are bigger, considering that milk production is greater in these systems (Table 1). The family income was very attractive, around $\mathrm{R} \$ 14,394.54$ /year for the creation of Saanen goats and $\mathrm{R} \$ 12,419.14$ to the creation of the Anglo Nubian.

However, it should be pointed out a very common problem in family farming that ends up confusing many producers, causing many of the systems are economically inefficient, this problem is precisely the workmanship. In this way, if it is considered that the production costs of the workmanship were counted, but in practice this value stays with the family, FI becomes $\mathrm{R} \$ 25,842.54$ and $\mathrm{R} \$ 23,867.14$ for the creation of Saanen and Anglo Nubian, respectively. In other words, these values correspond to 25.89 and 23.91 current minimum wages in the year 2019 in Brazil.

Table 6. Economic indicators for the production of 72 dairy goats in feedlot

\begin{tabular}{lcccccc}
\hline \multirow{2}{*}{ Breed } & \multicolumn{5}{c}{ Economic indicators } \\
\cline { 2 - 7 } & $\mathrm{RV}^{1}(\mathrm{R} \$)$ & $\mathrm{TC}^{2}(\mathrm{R} \$)$ & $\mathrm{FI}^{3}(\mathrm{R} \$)$ & $\mathrm{PL}^{4}$ & $\mathrm{RRe}^{5}(\%)$ & $\mathrm{TFP}^{6}$ \\
\hline Saanen & $48,600.00$ & $34,205.46$ & $14,394.54$ & 54.29 & 42.08 & 1.42 \\
Anglo Nubian & $45,350.00$ & $32,930.86$ & $12,419.14$ & 52.27 & 37.71 & 1.32 \\
\hline
\end{tabular}

${ }^{1} \mathrm{TR}:$ total revenue $=$ Revenue with the sale of milk, revenue from the sale of weaned goats for slaughter and revenue from the sale of young goats weaned for reproduction; ${ }^{2} \mathrm{TC}$ : total costs; ${ }^{3} \mathrm{FI}$ : family income; ${ }^{4} \mathrm{PL}$ : Point leveling; ${ }^{5} \mathrm{RRe}$ : rate of return the entrepreneur; ${ }^{6} \mathrm{TFP}$ : total factor productivity.

In relation to the point of leveling (PL) of systems it can be observed that the two scenarios had PL less than 72 goats that is the number of simulated animals in each scenario. The systems of creation of Saanen goats fed showed higher PL (54.29). In contrast, when you use the rearing of goats Anglo Nubian requires a smaller number of animals for which the sales values are higher than the total costs (52.27 goats). These data are very interesting, considering the number of animals falls as the number of animals found in small rural properties. The selling price of offspring produced was an item that influenced very significantly the results of economic analysis of two systems evaluated, considering that the production of milk may submit several bottlenecks, being the main one, the low price of milk sold. On the other hand, the sale of creates proved to be a viable income to the producer, because three pregnancies every two years provides the production of 216 young goats within a year, generating considerable revenue in both systems, around $\mathrm{R} \$ 48,600.00$.

Based on the above data, it can be argued that the creation of dairy goats may be considered, regardless of race, a viable investment. On the other hand, because this activity has a high economic impact on the profitability of the systems, it can be considered that the production and sale of milk, despite being an activity that depends on the behavior of the local economy, causes unfavorable variations in the prices of milk. marketing of milk paid to ranchers causes significant losses in the activity, given that this type of market is not yet well consolidated in the Chapadinha microregion, mainly due to the absence of dairy products intended for marketing, industrialization of goat milk, as in dairy cattle, in particular. that milk producing 
basins are well established in these requirements. Even so, we can observe that the FI of both systems was greater than zero, this indicates that the activity is stable and has the possibility of expansion (Guiducci et al., 2012). However, even if the net income was equal to zero, in conditions of competition in the production of goat milk, indicate the equilibrium in the long term, in which the producer would be able to pay all expenditure, i.e., to remunerate all factors of production. Thus, it can be argued that RF is an important indicator, since it helps to explain, in large part, the resistance of family farmers, who remain in productive activity even when FI receive equal to zero. This often occurs, and if justified, by obtaining a positive family income.

Another interesting indicator in the evaluated systems is the total factor productivity (TFP). Basically, the two systems showed TFP greater than 1, indicating that for each real invested in the creation, there is a return of $\mathrm{R} \$ 1.42$ and $\mathrm{R} \$ 1.32$ to systems of Saanen goats and Anglo Nubian, respectively. In the same way, the RRe was quite significant, showing that in both systems to FI corresponded to 42.08 and $37.71 \%$ of the total cost for the creation of the Saanen goats and Anglo Nubian, respectively.

It was observed that the financial analysis of both systems evaluated showed to be feasible over 8 years with the interest rate of $6 \%$ per year (Table 7). Both the NPV on the NPVa presented values and attractions for a small herd of dairy goats. It is interesting to observe that, in a general way, the system of creation with Saanen goats, presented higher values for the system of goat rearing of breed Anglo Nubian. In relation to the payback, you can observe that both scenarios presented low return on investment applied, with values of less than four years, approximately 3.07 years for the Saanen, i.e., after 1,120 days, since if they opt for the creation of the breed goats Anglo Nubian, this return will occur after 1,321 days (3.67 years). The payback is nothing more than the period of time necessary for the recovery of an investment. In other words, it is the time required for the negative cash flows (Investment) being canceled out by the positive cash flows (profits). Therefore, the two systems evaluated, soon in the third year of the sale of milk and goats there is return on investment.

Table 7. Financial Analysis for production of 72 dairy goats in feedlot

\begin{tabular}{lcccccc}
\hline \multirow{3}{*}{ Breed } & \multicolumn{7}{c}{ Financial Indicators } \\
\cline { 2 - 7 } & $\begin{array}{c}\mathrm{VPL}^{1} \\
(\mathrm{R} \$)\end{array}$ & $\begin{array}{c}\mathrm{VPLa}^{2} \\
(\mathrm{R} \$)\end{array}$ & $\begin{array}{c}\mathrm{PB}^{3} \\
(\text { years })\end{array}$ & $\begin{array}{c}\mathrm{IRR}^{4} \\
(\%)\end{array}$ & $\begin{array}{c}\mathrm{IRRm}^{5} \\
(\%)\end{array}$ & $\begin{array}{c}\mathrm{PI}^{6} \\
(\mathrm{R} \$)\end{array}$ \\
\hline Saanen & $66,625.07$ & $9,052.21$ & 3.07 & 3.48 & 17.04 & 2.69 \\
Anglo Nubian & $52,085.95$ & $7,076.81$ & 3.62 & 2.91 & 15.33 & 2.32 \\
\hline
\end{tabular}

${ }^{1} \mathrm{NPV}$ : Net Present Value; ${ }^{2} \mathrm{NPVa}$ : annualized net present value; ${ }^{3} \mathrm{~PB}$ : Payback; ${ }^{4} \mathrm{IRR}$ internal rate of return; ${ }^{5} \mathrm{IRRm}$ : modified internal rate of return (\%); ${ }^{\mathrm{PI}}$ : Profitability Index.

It can be concluded with these values that, if no drastic changes occur in the marketing of dairy goats in the study region, for the next eight years the market will be profitable. In practice this is expected because, in spite of this market find themselves in training, the trend is favorable, since the creation of dairy goats has presented inclination of growth, mainly in the northeast region of Brazil (Lôbo et al., 2017). It is also important to emphasize that the information used in the evaluations were projections for the future of the values of the variables that make up the 
cash flow and, therefore, are estimates subject to errors, such as, for example, mortality of young goats, something that makes the dairy goat has low zootechnical indexes (Lôbo et al., 2017).

Another limitation refers to the determination of the risk, once that, beyond the economic risk, there is the risk inherent to climatic conditions, because even if treating animals confined, dependence on the acquisition of the foods that make up the diets of these goats may change significantly, which can compromise the production of milk, considering that the cost with feeding has great significance in production costs (Table 3). On the IRR, IRRm and PI can be observed that the values for the creation of Saanen goats were higher. It should be noted, however, that in the case of the IRRm values in both systems are very attractive, because yield more than the passbook savings accounts (6\%/year), which were 17.04 and $15.33 \%$ for the Saanen and Anglo Nubian, respectively.

A sensitivity analysis of the production system of Saanen goats showed that, despite the more variables situations of changes in the price of calves and milk marketed or the quantity produced, the indicators of financial performance were still economically viable (Table 8). In the simulation of the most unfavorable system, for example, the NPV was R $\$ 5,343.79$, but with the payback exceeding 8 years, too much time for the return of the investment, positive internal rate of return of $0.66 \%$ to $5.38 \%$, IRRm, but below the rate of attractiveness that is $6 \%$, showing by this point of view, the activity is economically unviable. In the same way, the profitability index was below 1 , showing low efficiency in this situation. In a manner contrary to this situation, in an environment with recovery of $30 \%$ of the price of milk and offspring and at the same time, an increase of $30 \%$ in productivity, the performance indices are highly attractive, with emphasis on the payback of 2.32 years and IRRm of $23.08 \%$, almost double of that yields the passbook savings accounts.

Table 8. Sensitivity analysis for production of 72 dairy goats of Saanen breed fed in feedlot

\begin{tabular}{|c|c|c|c|c|c|c|c|}
\hline \multicolumn{2}{|c|}{ Combination } & \multicolumn{6}{|c|}{ Financial Indicators } \\
\hline Price & Quantity & $\mathrm{NPV}^{1}(\mathrm{R} \$)$ & $\begin{array}{c}\mathrm{NPVa}^{2} \\
(\mathrm{R} \$)\end{array}$ & $\begin{array}{c}\mathrm{PB}^{3} \\
\text { (years) }\end{array}$ & $\begin{array}{c}\mathrm{IRR}^{4} \\
(\%)\end{array}$ & $\begin{array}{c}\mathrm{IRRm}^{5} \\
(\%)\end{array}$ & $\begin{array}{l}\mathrm{PI}^{6} \\
(\%)\end{array}$ \\
\hline $30 \%$ & $30 \%$ & $112,203.51$ & $15,244.86$ & 2.32 & 10.52 & 23.08 & 4.51 \\
\hline $20 \%$ & $20 \%$ & $89,941.07$ & $12,220.11$ & 2.62 & 8.47 & 21.60 & 3.64 \\
\hline $10 \%$ & $10 \%$ & $69,459.62$ & $9,437.34$ & 2.98 & 6.58 & 19.94 & 2.85 \\
\hline$-10 \%$ & $-10 \%$ & $33,839.72$ & $4,597.73$ & 6.32 & 3.30 & 15.63 & 1.46 \\
\hline$-20 \%$ & $-20 \%$ & $18,701.25$ & $2,540.90$ & 7.40 & 1.90 & 12.50 & 0.87 \\
\hline$-30 \%$ & $-30 \%$ & $5,343.79$ & 726.05 & --- & 0.66 & 5.38 & 0.35 \\
\hline
\end{tabular}

${ }^{1}$ NPV: Net Present Value; ${ }^{2}$ NPVa: annualized net present value; ${ }^{3} \mathrm{~PB}$ : Payback; ${ }^{4}$ IRR internal rate of return; ${ }^{5} \mathrm{IRRm}$ : modified internal rate of return (\%); ${ }^{6} \mathrm{PI}$ : Profitability Index.

The production of goats Anglo Nubian showed a variation even greater than the Saanen (Table 9). We observed that in the simulation of a more pessimistic scenario, i.e., with a reduction of $30 \%$ as much of production as the price of the product, the internal rate of return was $0.92 \%$, but the IRRm was $8.22 \%$, i.e., greater than the rate of attractiveness, showing that even in a 
more unfavorable situation, goat rearing Anglo Nubian is more appropriate than the Saanen fed on the same diet, because the internal rate is higher than the rate of attractiveness of passbook savings accounts. However, as soon as the system of creation of Saanen goats, the return on investment will only happen after 8 years.

Table 9. Sensitivity analysis for production of 72 dairy goats of the Anglo Nubian fed in feedlot

\begin{tabular}{|c|c|c|c|c|c|c|c|}
\hline \multicolumn{2}{|c|}{ Combination } & \multicolumn{6}{|c|}{ Financial Indicators } \\
\hline Price & Quantity & $\begin{array}{c}\mathrm{NPV}^{1} \\
\text { (R\$) }\end{array}$ & $\begin{array}{c}\mathrm{NPVa}^{2} \\
(\mathrm{R} \$)\end{array}$ & $\begin{array}{c}\mathrm{PB}^{3} \\
\text { (years) }\end{array}$ & $\begin{array}{c}\mathrm{IRR}^{4} \\
(\%)\end{array}$ & $\begin{array}{c}\mathrm{IRRm}^{5} \\
(\%)\end{array}$ & $\begin{array}{l}\mathrm{PI}^{6} \\
(\%)\end{array}$ \\
\hline $30 \%$ & $30 \%$ & $129,519.51$ & $17,597.55$ & 2.54 & 14.55 & 28.85 & 4.51 \\
\hline $20 \%$ & $20 \%$ & $103,821.38$ & $14,106.00$ & 2.98 & 11.71 & 27.07 & 3.64 \\
\hline $10 \%$ & $10 \%$ & $80,179.10$ & $10,893.77$ & 3.04 & 9.13 & 24.92 & 2.85 \\
\hline$-10 \%$ & $-10 \%$ & $39,062.09$ & $5,307.29$ & 6.56 & 4.56 & 19.55 & 1.46 \\
\hline$-20 \%$ & $-20 \%$ & $21,587.36$ & $2,933.03$ & 7.67 & 2.63 & 14.63 & 0.87 \\
\hline$-30 \%$ & $-30 \%$ & $6,168.48$ & 838.10 & --- & 0.92 & 8.22 & 0.35 \\
\hline
\end{tabular}

${ }^{1} \mathrm{NPV}$ : Net Present Value; ${ }^{2} \mathrm{NPVa}$ : annualized net present value; ${ }^{3} \mathrm{~PB}$ : Payback; ${ }^{4} \mathrm{IRR}$ internal rate of return; ${ }^{5} \mathrm{IRRm}$ : modified internal rate of return (\%); ${ }^{6} \mathrm{PI}$ : Profitability Index.

\section{Conclusions}

The highest profitability is achieved by systems that opt for the creation of Saanen goats. The costs with power, opportunity and labor were the items that more overburden in both scenarios assessed. The economic analysis shows that production costs are higher in the creation of Saanen goats, however the family income will be greater.

Sensitivity analyzes showed that in both systems evaluated, only in the most unfavorable situations, the indicators of financial performance are not attractive, given that the time of return on investment is too long, especially in the creation of Saanen, because for the Anglo Nubian, a situation totally unfavorable resulted in lower economic losses.

\section{References}

Araújo, R. A., Neiva, J. N. M., Pompeu, R. C. F. F., Cândido, M. J. D., Rogério, M. C. P., Lucas, R. C., Maranhão, S. R., Fontinele, R. G., \& Egito, A. S. (2018). Feeding behaviour and physiological parameters of rearing goats fed diets containing detoxified castor cake. Semina: Ciências Agrárias, 39(5), 2247-2260. https://doi.org/10.5433/1679-0359.2018v39n5p2247

Araújo, R. A., Neiva, J. N. M., Rogério, M. C. P., Pimentel, P. G., Furtado, R. N., Mariz, L. D. S., ... Pompeu, R. C. F. F. (2019). Ingestive behavior and physiological parameters of lactating goats fed diets containing detoxified castor cake. Biological Rhythm Research, 50(1) 1-11. https://doi.org/10.1080/09291016.2019.1594120

Dal Monte, H. L., Costa, R. G., Holanda Júnior, E. V., Pimenta Filho, E. C., Cruz, G. R. R. \& Menezes, M. P. C. (2010). Calculation of the costs and evaluation of incomes in different systems of production of goat milk in Cariris Paraibanos. Revista Brasileira de Zootecnia, 39(11), 2535-2544. https://doi.org/10.1590/S1516-35982010001100029 
Guiducci, R. C. N., Alves, E. R. A., Lima Filho, J. R., \& Mota, M. M. (2012). Aspectos metodológicos da análise de viabilidade econômica de sistemas de produção. In: Guiducci, R. C. N., Lima Filho, J. R. \& Mota, M. M. (Ed.). Viabilidade econômica de sistemas de produção agropecuários: metodologia e estudos de caso. Brasília, DF: Embrapa. p. 17-78.

Lôbo, A. M. B. O., Lôbo, R. N. B., Facó, O., Souza, V., Alves, A. A. C., Costa, A. C., \& Albuquerque, M. A. M. (2017). Characterization of milk production and composition of four exotic goat breeds in Brazil. Small Ruminant Research, 153(1), 9-16. https://doi.org/10.1016/j.smallrumres.2017.05.005

National Research Council-NRC. (2007). Nutrient Requirements of Small Ruminants. National Academy Press, Washington, DC.

Pinto, C. W. C., Costa, J. M. O., \& Nobrega Jr, J. E. (2014). Alternativa para produção de cordeiros Santa Inês em confinamento, alimentados com subprodutos da agroindústria. Revista Agropecuária Técnica, 35(1), 185-190.

Stivari, T. S. S., Chen, R. F. F., Gameiro, A. H., Monteiro, A. L. G., Raineri, C., \& Silva, J. B. A. (2014). Feasibility of grazing sheep production systems using long-term economic indicators and the methodology of the soil expectation value. Brazilian journal of veterinary research and animal 149-157. https://doi.org/10.11606/issn.1678-4456.v51i2p149-157

Vieira, V. D., Riet-Correa, W. R., Vilela, V. L. R., Medeiros, M. A., Batista, J. A., Melo, L. R. B., Santos, A., \& Riet-Correa, F. (2018). Controle de parasitas gastrintestinais em ovinos e análise financeira de uma fazenda com sistema de pastejo rotacionado irrigado no semiárido nordestino. Pesquisa Veterinária Brasileira, 38(5), 913-919. https://doi.org/10.1590/1678-5150-pvb-5400

Ziguer, E. A., Tonieto, S. R., Pfeifer, L. F. M., Bermudas, R. F., Schwegler, E., Corrêa, M. N. \& Dionello, N. J. L. (2011). Resultados econômicos da produção de cordeiros em confinamento utilizando na dieta casca de soja associada a quatro fontes de nitrogênio não-proteico. Revista Brasileira de Zootecnia, 40, 2058-2065. https://doi.org/10.1590/S1516-35982011000900030

\section{Copyright Disclaimer}

Copyright for this article is retained by the author(s), with first publication rights granted to the journal.

This is an open-access article distributed under the terms and conditions of the Creative Commons Attribution license (http://creativecommons.org/licenses/by/4.0/). 